\title{
Human Rights violation in Indian-administered Kashmir and role of United Nations, 1989-2019
}

\author{
Naruszenie praw człowieka w administrowanym \\ przez Indie Kaszmirze i rola \\ Organizacji Narodów Zjednoczonych, 1989-2019
}

Roshan Sheikh*

\begin{abstract}
This article focuses on Human Rights violations and resolutions passed by the United Nations. This study points to the oppression, seige, hard power policy, and the Indian occupation of Indian-administered Kashmir. The article continues to deal with the possible negotiation on the Kashmir conflict between India and Pakistan. Therefore, it particularly emphasizes the role of the United Nations in the Kashmir conflict. It elaborates on the failure of United Nations resolutions on Kashmir conflict and rejection of 3rd party intervention by the Indian Government. The responsibility of the international community in Kashmir is to respect Human Rights, the failure of which has resulted in physical and mental trauma. The aim of the
\end{abstract}

\begin{abstract}
Abstrakt
Niniejszy artykuł zajmuje się łamaniem praw człowieka w Kaszmirze i rezolucjami podjętymi przez Organizację Narodów Zjednoczonych w tej kwestii. Opracowanie to wskazuje na indyjski ucisk, ofensywy, politykę twardego kursu i okupację administrowanego przez Indie Kaszmiru. Kolejną kwestią podjętą $\mathrm{w}$ artykule są możliwe negocjacje w sprawie konfliktu w Kaszmirze między Indiami a Pakistanem. Dlatego też opracowanie to podkreśla szczególną rolę Organizacji Narodów Zjednoczonych w tymże konflikcie. Ponadto omówione są niepowodzenia rezolucji ONZ w sprawie konfliktu w Kaszmirze i odrzucenie interwencji stron trzecich przez rząd Indii. Brak odpowiedzialności społeczności międzynarodowej w kwestii przestrzega-
\end{abstract}

* Faculty of Political Science and International Studies, University of Warsaw (roushanakbar@gmail.com); https://orcid.org/0000-0001-9269-8722. 
article is to evaluate the UN policy toward Kashmir Human Rights problems.

Keywords: Kashmir, UN, India, Pakistan, Human Rights, Security nia praw człowieka w Kaszmirze skutkuje fizyczną i psychiczną traumą tamtejszej społeczności. Celem tego artykułu jest także ocena polityki ONZ wobec problemów związanych z prawami człowieka w Kaszmirze.

Słowa klucze: Kaszmir, ONZ, Indie, Pakistan, prawa człowieka, bezpieczeństwo

\section{Introduction}

The seeds of Kashmir conflict were sown at the time of partition by the last British Viceroy, Louis Mountbatten, followed by the accession of princely states. India got its independence from the British and two Nations came into existence as India and Pakistan on August 15 and 14, 1947 respectively based on the twonation theory. At the time of partition Kashmir was asked to join either India or Pakistan with the geographical contiguity and wishes of the people. To remain independent was also an option that Maharaja Hari Singh (ruler of Kashmir) had to decide on.

The decision about the accession of Kashmir becomes complex because of its ethnic-regional complexion. It was supposed that Muslim majority states would join Pakistan and Hindu majority states would join India, including other princely states (Tremblay, 2009). According to the 1941 census, Kashmir had the Muslim population of 77.11 percent (Kumar, 2019). There were strong chances to join Pakistan except for Maharaja Hari Singh's indecisiveness. The collective conscience of Maharaja Hari Singh, the influence of political pressure and favorable to be secular and democratic made Maharaja Hari Singh sign the Instrument of Accession on October 26, 1947 (Noorani, 2013).

The first war between the two newly independent states broke out when the Indian Army landed in the state on October 27, 1947. Because of the geopolitical location of Kashmir, it has always been a center of interest between two countries which led both countries to fight three wars in 1947, 1965 and 1999 and another war over Bangladesh in 1971 in which Kashmir was a secondary issue. Kashmir has never been satisfied with the influence of India, because of which in 1990 circumstances intensified and became medium of ongoing political discourse (Zaidi 2003).

In 1989, a mass revolt started against India in Kashmir which took attention by the international community. Following the 1999 Kargil war, the 2001 Indian Parliament attack and 2008 Mumbai attacks created havoc in Kashmir. In the 
21st century, Kashmir witnessed uprisings in which the youth, who took arms and started protesting against India, were a major concern (Kapur, 2010).

Thus, throughout the examples and historical outline of the conflict presented, this article aims at validating the role of the international community in the Kashmir conflict between India and Pakistan. The violation of human rights in conflict areas represents a larger threat to security and sustainable peace.

Research Question: How have human rights in Indian Administrared Kashmir been violated since 1989 and what role has been played by the United Nations? Hypothesis: Since 1989 (uprisings in Kashmir), human rights have been violated using different methods, such as mass rapes, tortures, enforced disappearances, use of pellet gun, which is a clear violation of human rights and against International Law. The role of the United Nations, its policies and intervention, is crucial and needs to be studied.

Methodology: A qualitative content analysis of the desktop-based study is adopted in this research. Content analysis is a set of qualitative methods for collecting and analyzing data from verbal and print sources. The basic principles of a qualitative content analysis include categorical workings, units of analysis validity and reliability. The central procedure of qualitative content analysis, inductive development of categories, deductive application of categories, will be worked out.

\section{Political, military and social situation in Indian-administered Kashmir}

Kashmir is classified as the largest region administrated by security forces. More than half a million Indian military forces are deployed in the state of Kashmir with authoritarian laws, such as AFSPA (Armed forces special power act, 1958), PSA (Public safety act, 1978) and DAA (Distributed area act, 1997). These acts grant armed forces extraordinary powers, including powers to arrest and enter at any place without a warrant. Human rights organizations, like Amnesty International, have challenged AFSPA on the basis that it violates basic human rights (D'costa, 2018).

For every eight Kashmiris, there is an Indian Military soldier. Indian military forces are involved in many fake encounters that have shed many innocent lives of Kashmiris. The high ratio of troops to civilians makes Kashmir valley the most heavily militarized area in the world. The military and paramilitary units in Kashmir most notably comprise the Border Security Force (BSF), the Central Reserve Police Force (CRPF), Rashtriya Rifles (RR), Special Task Force (STF) and the Special Operations Group (SOG) (Duschinski, 2009). 
Meanwhile, the saturation tactics of these armed forces include checkpoints, surveillance, cordon and search operations, human shields, prison detention, and torture. The landscape of Kashmir is mapped by official and unofficial stations of state violence, cantonments, barracks, joint interrogation centers, and detention facilities. Kashmir lives in constant fear of arbitrary arrests, enforced disappearances, sexual harassment, torture, and custodial death. Given the sweeping power afforded to security forces through the special acts, Kashmiris refer to their homeland not as a "disputed area" but an "administered zone," a bunkered territory and a garrisoned state (Grossman, 1996).

\section{Enforced disappearances in the conflict zone}

Kashmir has around 8,000 families who had lost their loved ones during the conflict. These disappearances are at the behest of Indian armed forces but they refuse to acknowledge the problems and take action (Kazi 2007). According to the UN, "An enforced disappearance occurs when people are arrested, detained or abducted against their will by the state, or groups and individuals acting on behalf of, with support from the state followed by a refusal to disclose the whereabouts of the person."

Enforced disappearances in Kashmir started in 1989, followed the outbreak of armed conflict. The heavy deployment of security forces as part of the effort to suppress the movement for independence has contributed fundamentally to this problem. Enforced disappearance of persons is part of the bigger policy of tyranny followed by the state, including other means such as extra-judicial killings, torment, assault, constrained work. An enormous number of civilians, students, political activists, and militants have disappeared in custody bothering direct central rule from 1989 until 1996 as well as a rule by elected state Government from 1996 to 2004 (Lauritsch, 2009). According to the Asian Federation Against Involuntary Disappearances, "At a conservative estimate based on information collected from parents, relatives, friends, near and dear ones, the number of individuals who have disappeared in the custody since 1989 is as high as 8,000."

The Indian state's consistent uncaring approach has constantly denied the unfortunate casualty groups of truth, equity and reparations, with the outcome the groups of disappeared including guardians, half widows, and half vagrants kept on enduring perpetually in the journey to know the destiny and whereabouts of their friends and family. Up until this point, the government has never demonstrated any worry over the situation of thousands of families of the disappeared in Kashmir and stead it has consistently stayed over-worried about the resolve of their armed forces for whom there is total invulnerability (Parvez 2010). 
Human rights and security are two notions that have been developed in parallel. The absence of one has historically proven to be a risk for the other. Unpunished crimes and failure to provide justice as well as protecting oneself through absolute immunity are only some of the factors that lead to the fragility of the peace and security situation.

\section{The examples of Human Rights violation in Indian-administered Kashmir}

The United Nations was founded on the base to protect the human rights and dignity of all human beings in the world (UN General Assembly 1948). At the insurgency in the Kashmir Valley gained momentum, the act of sabotage increased in terms of frequency and intensity. The security forces and paramilitary troops reacted violently often at the expense of innocent civilians. The abuse of human rights by the security forces has been a persistent and serious cause for concern. Stories have emerged of torture, rape, and indiscriminate killings. Murder, extortion, and intimidation have not only crippled the economy but also have created a climate of fear. At one time Kashmir was a tourist paradise, now it has been converted into a martyr's graveyard (Hilali, 2001).

Kashmir has been turned from paradise into a desert. The picture is one of the revolts, mutiny, and destruction. The loss of property, schools, hospitals, bridges, and killing has come to the commerce of everyday life throughout the Kashmir Valley. Innocent and harmless people have been left handicapped in torture cells and a large number have been given inhuman treatment in various prisons. The lives of Kashmiris have been convulsed by lamb attacks, reprisals, cross-fire, and curfew. Homes have been raided and sometimes destroyed because of frequent security operations (Bashir, 2016). Moreover, from 1989, the Kashmiris have lived in fear of the gun (Walter R. Lawrence, 1895).

According to the Kashmiri-Canadian Council, "6300 Kashmiri women have been raped." In Kashmir, rape is used as a method of humiliation and frighten to attack Kashmiri women by Indian security forces. Rape is considered a weapon of war in many conflict areas. By raping women, the security forces are aiming at punishing and humiliating the entire community. The vulnerable victims are generally women from low-caste, necessitous and tribal in minority groups.

In some cases, women are detained as hostages and taken into custody as suspected in petty crime (Sarma, 2016). Molen and Bal state that there is a tendency in Kashmir to refuse to marry anyone from a village where rape has been committed. Kunan Poshpora incident and Shopian rape and murder case in the 
year 1991 and 2009 respectively are the examples of brutality and inhuman barbarism of Indian forces (Bora 2010). However, as Shubh Mathur calls, "Rape is an indispensable element of the armed forces strategy in Kashmir." According to the 1993 Human Rights Watch (HRW), "The Indian security forces use rape as a method of retaliation against Kashmiri civilians."

The law enforcement engaged in torture and other cruel, inhuman and degrading treatment or punishment in the name of security threats. The state uses violence methods to control and terrorize its people to maintain the status quo or to destroy internal or external political, ideological or military threats (Irwin M. Cohen, 2005). The state uses torture and makes it clear that enhanced interrogation techniques make a person handicapped. The valley of Kashmir has been facing torture and other inhuman cruel treatments since the insurgency began in 1990. Methods of torture are used as a tool of counter-insurgency by Indian security forces (Sharma, 2010).

The Indian government used all efforts to crush the movement of selfdetermination of Kashmiris. Kashmiris have been offering resistance to external aggression. Thousands are arrested and subjected to extra-judicial killings. The custodial killings became a routine in the 1990s. According to the Human Rights Defenders, around 12,000 custodial killings have been reported during the past 28 years. Many are those who lost their beloved children, daughter, sisters, mothers and some women have lost their beloved husband, who was the only source of care for them.

According to the Amnesty International report of September 2017, Pallet gun has been used by security forces in Kashmir since 2010. Pallet gun is a pumpaction shotgun firing hundreds of metal pallets which spead over a wide area. Pallet guns were first introduced for crowd control as "non-lethal" alternatives to other deadlier weapons. Nevertheless, in 2010 two youths lost their lives to pellet gun injuries (Bukhari 2015). As per reports in Wire magazine, "It is reported that at least 92 people have lost their eyesight and at least 1500 people have sustained serious injuries from pellet guns since 2010.” Pellet guns are used by Indian troops on to blind Kashmiris. The use of a pellet gun is a clear violation of Human rights and humanitarian law (Nair, 2016).

According to Thakur, due to the cycle of violence, the life of Kashmiri citizens is remaking paralyzed, where all educational institutions are forcibly closed for an indefinite period. In addition, it can be said every Kashmiri has suffered in one way or another. Kashmiri youths are killed in the name of the encounter, women are molested and raped, and older men are dishonoured. Indian armed forces and other paramilitary troops are backed by Indian Governments (Thakur, 2000).

The first ever report on Human rights by Office of the United Nations High Commissioner for Human Rights (OHCHR) of June 14, 2018 urged India to end human rights violations in Kashmir. According to 49 pages report from 
the OHCHR, "This is an urgent need to address past and ongoing human rights violations, abuses and deliver justice for all people in Kashmir, who for seven decades have suffered a conflict that has claimed or ruined numerous lives."

Bifurcation of the state of Jammu and Kashmir and aftermath of the abrogation of the Article 370 and 35A in August 2019 (Nair, 2019) led Kashmir under siege for more than 5 months. During the protest in Kashmir telecommunication was snaped and newspapers were banned (Kaul, 2018). However, partition of India and Paikistan has played an important role in ongoing crisis in the region (Zutshi, 2015).

Many articles and studies have been conducted and published on the role of the United Nations in Kashmir conflict in regard to its resolutions. For example, Josef Korbel blamed British colonialism for the birth of the conflict. Alex Ninian, Shabir Choudhry, Seema Shekhawat, and Eric Margolis stressed that mutual suspicion, hatred, and anger have almost thwarted the long-standing agreement between the governments of India and Pakistan, and prevented the fate of Kashmir being decided by the democratic process of plebiscite. However, this article explains the continuous intervention and failure of the international community.

\section{The role of United Nations in protection of Human Rights and resolution of the Kashmir conflict}

The contemporary political and legal theories link democracy with accountability as a mutual approach or double way doctrine where democracy and accountability promote and support each other. On January 1, 1948, India took the Kashmir conflict in front of the United Nations Security Council in which they complained to Pakistan under Article 35 (Chapter VI) of the UN Charter. However, Pakistan repudiated all the charges of facilitating tribal infilitration in Kashmir and blamed India for destabilizing Pakistan in its infancy (Behera 2006).

The UN Security Council passed 23 resolutions on Kashmir conflict between 1948 and 1971. The first UN debate on Kashmir started under the title of "Kashmir Question." The resolutions passed were aimed at solving the Kashmir conflict. Despite these efforts, the Kashmir conflict is the oldest unsolved conflict in front of the UN (Bose 2003).

The article points to the role of the UN in urging India and Pakistan to curtailment and to ease the tension. On January 20, 1948, the UN adopted the resolution on the Kashmir conflict at the 230th meeting. The committee chosen was set up with three members from whom one member was to be chosen by Pakistan and other by India. The third member of the committee was to be 
chosen by the other two members of the committee. The aim of forming the committee was to be to write a joint proposal for stating what actions can be taken in the region for peace. The proposal did not get implemented and failed and gave birth to other resolutions.

\section{Plebiscite in Kashmir}

After the first war between India and Pakistan on Kashmir the UN adopted the resolution on the Kashmir conflict at the 286th meeting. Belgium, Canada, Columbia, China, the United Kingdom and the United States of America sponsored the resolution. The resolution was carried out on hearing the arguments from both India and Pakistan and instructions were given by the Security Council to the commission to go to the subcontinent and help restore peace and order in the region and prepare a referendum to decide the fate of Kashmir. The resolution passed under Chapter VI of the UN charter is considered non-binding and has no mandatory enforceability as opposed to the resolution passed under Chapter VII.

According to official documents of the United Nations Security Council, the free and impartial plebiscite through a democratic voting process should be held for the accession of Kashmir to India or Pakistan. The Government of India should delegate to the plebiscite administration such powers as it considers necessary for holding a fair and impartial plebiscite. The purpose of state forces and police will be direction and supervision.

However, the study shows that the resolution was partial for both the states and was applicable in front of the Government of India and Pakistan. The resolution could not be implemented due to insecurity and lack of trust between India and Pakistan. Even though the United Nations had passed many resolutions over several years, they were not implemented as a result of which India and Pakistan started playing the blame game with each other over Kashmir. Consequently, both India and Pakistan could not agree on any proposal (Korbel, 1949).

\section{Demilitarisation in Indian-administered Kashmir}

The study shows the plan of demilitarization in Kashmir. Sir Dixon points on functions of Government in the state necessary to ensure a fair and free plebiscite and extent plan of demilitarization. The United Nations Security Council 
accepted Sir Owen's resignation and expressed its appreciation to him for his great potential and devotion. The Council appointed Frank Graham in replacement as the representative of the UN and emphasized on finding ways towards peaceful solutions and carrying the plan of demilitariation (Noorani, 2013).

The report on demilitariation shows that after receiving the report by Dr. Frank Graham and addressing the plan of demilitariation before the Council, the report was noted and approved. The Council accepted the principle that the accession of the state should be determined by the free and impartial plebiscite under the supervision of the UN. The Council also noted the satisfaction over India and Pakistan for the work on a peaceful settlement and continued to observe a ceasefire. The UN then instructed the representative to continue efforts to obtain agreement on a plan for demilitarizing Kashmir and to report to the Security Council within six weeks (Grossman, 1996).

The Resolution 98 was adopted on negotiations to reach an agreement on a plan of demilitarization of the state of Kashmir. The resolution urged both the Governments to reach an agreement on the specific number of troops to remain on each side of the ceasefire line. The number of troops was to be between 3,000 and 6,000 on the Pakistani side and 12,000 to 18,000 on the Indian side. Both Governments were supposed to report to the Council not later than in 30 days. Dr. Frank Graham carried the major part of the resolution and the implication of the resolution did not come true between India and Pakistan as the conflict remains between the two states (Ashraf, 2002).

Furthermore, the study shows that the number of the Indian troops has risen from 18,000 troops in 1952 to 1,000,000 troops at present times (Cheema, 2015).

\section{Proposals by United Nations Security Council}

The study shows that the Security Council submitted proposals after hearing the statements from representatives of the Government of India and Pakistan concerning the conflict over Kashmir. The resolution declared that the assembly proposed by the Jammu and Kashmir National Conference could not contribute a solution to the problem as per the United Nations Security Council resolution 91 (1951). On February 21, during the 774th meeting the Security Council recalled its resolution 122 of January 24, its previous resolutions and the resolution of the United Nations Commission for India and Pakistan (Behera 2006). The representative of Sweden was requested by the president of the Security Council to examine with the Governments of India and Pakistan any proposals which in his opinion are likely to contribute towards the settlement of the conflict having regard to the previous resolutions of the Security Council. The 
United Nations Commission for India and Pakistan was to visit the subcontinent for this purpose and to report to the Security Council not later than April 15, 1957. The Governments of India and Pakistan were invited to cooperate with him in the performance of these functions. Futhermore, the Secretary-General and the United Nations representative for India and Pakistan were requested to render such assistance as he may request. The representatives were expected to make any proposals to the parties for supplementary apt action with a view of making progress towards the enactment of the resolution of the United Nations Commission for India and Pakistan of August 13, 1948 and January 5, 1949 towards a peaceful settlement. The authorized United Nations representative visited the sub-continent for these purposes. The United Nations representative was instructed to report to the Security Council on his efforts as soon as possible (Ashraf, 2002).

The article evaluates that the role of the United Nations was almost eliminated after the 1965 War on Kashmir between India and Pakistan. Both the Governments signed the Tashkent declaration, according to which, "Minister level talks were to be held on the Kashmir conflict." This attempt also remained unsuccessful because of the difference of opinion. The several sessions and hard work of the United Nations on the Kashmir conflict could not find a solution (Channah, 1978).

\section{The evaluation of the UN policy towards Kashmir Human Rights problems}

This article presents many examples of how both Governments of India and Pakistan accepted Kashmir as a disputed territory before the United Nations, but back at home some groups never considered Kashmir as a disputed territory (Bose, 2003). It was the United Nations Security Council that tried the best of its capacity to resolve the issue by several resolutions, but their work did not help both countries to solve the issue. India and Pakistan claimed Kashmir as an integral part which was being forcefully controlled by the opposition. Both countries could not make any bold decisions because of the pressure from their people and fear of decision which might cost them heavily. However, Pakistan on some occasions was in favor of referendum despite the widespread feeling in India that Kashmir was its integral part. The Indian Government always halted the progress by making different excuses to reject the United Nations proposals (McMahon, 1994). 


\section{Conclusion}

This article presented some of the most important evidence on how the solution of the Kashmir conflict is inevitable within the guidelines and framework of the United Nations charter which is founded on principals to save succeeding generations from the scourge of war. However, the role of the UN in resolving the crisis is emulsified. The UN must perceive the Kashmir issue as its top priority and bring a resolution mechanism to both parties to the conflict.

The findings also suggest that the history of Kashmir negotiations is marked by a series of failures, lack of trust and mutual suspicion on the part of both India and Pakistan. Several times negotiation took place but ultimately ended without constructive results. From 1948 (1st resolution) to 2018 India did not accept any proposal concerning demilitarisation and holding a plebiscite in Kashmir. India rejects third-party mediation based on the fact that it would expose actuality of Kashmir conflict whereas Pakistan invites third-party mediation for resolving the Kashmir conflict.

Therefore, this article presented satisfactory evidence that as an international community, it can pave a way to peace and prosperity in conflict areas like Kashmir. Paradigm shift could be made when India, Pakistan, and Kashmir will accept the resolution of the United Nations; otherwise, it would be a tough task to be resolved.

\section{References}

Ashraf, F. "Jammu and Kashmir Dispute: Examining various proposals for its Resolution." issi, 2002: 5-19.

Bashir, T. The Portrayal of Human Predicament in Contemporary Kashmiri Literature. PhD Thesis, Delhi: Shodhganga, 2016.

Behera, N. C. Demystifying Kashmir. Washington, D.C.: Brookings Institution Press, 2006.

Bora, M. S. "Rape Cases.” In Report of Independent People's Tribunal on Human Rights Violation in Kashmir, by Harsh Dobhal, 26-35. New Delhi: Human Rights Law Network, 2010.

Bose, S. Kashmir: Roots of Conflict, Paths to Peace. London: Harvard University Press, 2003.

Bukhari, Mannan. Kashmir - Scars of Pallet Gun: The Brutal Face of Suppression. Srinagar: Partridgepublishing, 2015.

Channah, B. Indo-Pakistan Relations. PhD Thesis, Amherst: ScholarWorks, 1978. 
Chaudhary, S. "Extraordinary Military Powers and Right to Self Determination in Kashmir." TSpace, 2013: 43-63.

Cheema, M. J. "Pakistan — India Conflict with Special Reference to Kashmir." Lahore: South Asian Studies: A Research Journal of South Asian Studies, 2015.

D'costa, John Braithwaite and Bina. "War, Crime and Peacebuilding Across South Asia." In Cascades of Violance, by John Braithwaite and Bina D'costa, 177269. ANU Press, 2018.

Duschinski, H. Destiny Effects: Militrization, State Power, and Punitive Containment in Kashmir Valley. NW Washington DC: The George Washington University Institute for Ethnographic Research, 2009.

"First-ever UN human rights report on Kashmir calls for International inquiry into multiple violations." Office of the high commissioner UNHRC, Geneva, 2018.

Grossman, P. India's Secret Army in Kashmir: New Patterns of Abuse emerge in the Conflict. Research Report, New York City: Human Rights Watch/Asia, 1996.

Hilali, A. Z. "Kashmir: Emerging Nuclear Threat in South Asia." jstor, 2001: 34-56.

Imroz, P. Kashmir: Enforced Disappearances In Jammu and Kashmir. Quezon City, Philippines: Asian Fedration against Involuntry Disappearances, 2005.

Irwin M. Cohen, Raymond R. Corrado. "State Torture in the Contemporary World." sagepub, 2005: 103-131.

Kapur, Sumit Ganguly and S. Paul. India, Pakistan, and the Bomb: Debating Nuclear Stability in South Asia. New York City, United States: Columbia university Press, 2010.

Kazi, S. Between democracy and Nations: Gender and Militarisation in Kashmir. PhD Thesis, Ann Arbor, MI, United States: ProQuest LLC, 2007.

Kaul, N. India's Obsession with Kashmir: Democracy, Gender, (Anti) Nationalism. Academia, 2018.

Korbel, J. "The Kashmir Dispute and the United Nations." jstor, 1949: 1-10.

Kumar, N. Politics and Religion in India. London: Taylor \& Francis. 2019.

Lauritsch, K. "Enforced Disappearances in Democratic Countries." In We need the truth: Enforced Disappearances in Asia, 70-83. ECAP - Equipo de Estudios Comunitarios y Accion Piscosocial, 2009.

McMahon, R. J. The Cold war on the periphery: The United States, India and Pakistan. New York: Columbia University Press, 1994.

Nair, R. "Pallet Guns in Kashmir: The Lethal use of "Non-Lethal" Weapons." The Wire, 07 21, 2016.

Nair, B. G. Abrogation of Article 370: can the president act without the recommendation of the constituent assembly? Taylor \& Francis, 2019.

Noorani, A. G. The Kashmir Dispute. Oxford, England: Oxford University Press, 2013.

Official documents by un.org from 1947-2018.

Parvez, K. "Half Widows and Orphans — A way forward in Islamic Jurisprudence." The Voice, 2010: 11-16.

Pérez Sola, M. F. Enforced Disappearances. Jefferson, North Carolina: McFarland and Company, Inc. Publishers, 2006. 
Sarma, P. G. “Rapes in India during 1991-2014." Telangana journal of Psychiatry, 2016: $11-14$.

Sharma, M. Human Rights in a Globalised World. New Delhi: Sage Publishing, 2010.

Thakur, H. K. "Human Rights Problem in Kashmir." In Alienation and Integration in Jammu and Kashmir, 210-249. Jaipur: Rawat Publishers, 2000.

Tremblay, R. C. “Kashmir's secessionist movement resurfaces.” jstor, 2009: 24-50.

Walter R. Lawrence, I. C. S., C. I. E. The Valley of Kashmir. London: Oxford University Press, 1895.

Zaidi, S. H. "The Intractable Kashmir: Search for a Rational Solution.” JSTOR, 2003: $07-23$.

Zutshi, C. An ongoing partition: histories, borders, and the politics of vivisection in Jammu and Kashmir. Contemporary South Asia, 2015. 